\title{
ANALISIS BUTIR SOAL UJIAN AKHIR SEKOLAH (UAS) MATA PELAJARAN MATEMATIKA PADA TAHUN AJARAN 2015/2016 SMP NEGERI 36 MAKASSAR
}

\section{ANALYSIS OF GRAIN PROBLEMS OF SCHOOL FINAL EXAMS (SFE) MATHEMATICS STUDY AT 2015/2016 ACADEMIC YEAR MIDDLE SCHOOL 36 MAKASSAR}

\author{
Andi Surahma Halik ${ }^{1)}$, Sitti Mania'), Fitriani Nur ${ }^{3}$ ) \\ 1,2,3)Fakultas Tarbiyah dan Keguruan Universitas Islam Negeri Alauddin Makassar \\ andisurahma.halik@gmail.com ${ }^{11}$, , sitti.mania@uin-alauddin.ac.id ${ }^{2}$, , fitriani.nur@uin-alauddin.ac.id ${ }^{3}$ )
}

\begin{abstract}
Abstrak
Penelitian ini bertujuan untuk mengetahui kualitas butir soal ujian akhir sekolah mata pelajaran matematika pada tahun ajaran 2015/2016 SMP Negeri 36 Makassar dilihat dari segi tingkat kesukaran, daya beda, dan keefektifan pengecoh. Penelitian ini merupakan penelitian yang bersifat evaluasi dengan pendekatan deskriptif kuantitatif. Penelitian dilakukan dengan sampel sebanyak 258 lembar jawaban siswa. Teknik pengumpulan data yang digunakan adalah teknik dokumentasi. Data yang diperoleh dianalisis dengan bantuan aplikasi Anates versi 4.09. Hasil penelitian menunjukkan bahwa: (1) Berdasarkan kriteria tingkat kesukaran diperoleh soal sangat mudah 2 butir (5\%), sedang 24 butir (60\%), sukar 12 butir (30\%), dan sangat sukar 2 butir (5\%). (2) Berdasarkan kriteria daya beda diperoleh soal sangat jelek 3 butir $(7,5 \%)$, jelek 12 butir (30\%), cukup 14 butir (35\%), dan baik 11 butir (27,5\%). (3) Berdasarkan keefektifan pengecoh diperoleh 28 butir (70\%) kategori sangat baik, 9 butir (22,5\%) kategori baik, dan 3 butir $(7,5 \%)$ kategori buruk. Berdasarkan hasil analisis dapat disimpulkan bahwa 15 butir $(37,5 \%)$ soal berkualitas baik, 16 butir (40\%) soal berkualitas kurang baik, dan 9 butir $(22,5 \%)$ soal berkulitas jelek. Butir soal yang berkualitas baik dapat dimasukkan ke bank soal, butir soal kurang baik dapat direvisi, dan butir soal yang jelek diganti dengan membuat soal baru.
\end{abstract}

Kata Kunci: daya pembeda, efektifitas opsi, tingkat kesukaran

\begin{abstract}
This study aims to determine the quality of mathematics final exam items in the 2015/2016 academic year 36 Makassar Junior High School in terms of the level of difficulty, different power, and effectiveness of deceivers. This research is an evaluation study with a quantitative descriptive approach. The study was conducted with a sample of 258 student answer sheets. The data collection technique used is the documentation technique. The data obtained were analyzed with the help of the Anates application version 4.09. The results showed that: (1) Based on the difficulty level criteria, 2 items (5\%), 24 items (60\%) were very easy, 12 items (30\%), and 2 items (5\%) were very difficult. (2) Based on the different power criterion, it is obtained a very poor problem of 3 items (7.5\%), 12 items bad (30\%), enough 14 items (35\%), and good 11 items (27.5\%). (3) Based on the effectiveness of the deception, there were 28 items (70\%) in the very good category, 9 items (22.5\%) in the good category, and 3 items (7.5\%) in the bad category. Based on the results of the analysis it can be concluded that 15 items (37.5\%) of good quality questions, 16 items (40\%) of poor quality questions, and 9 items (22.5\%) of poor quality questions. Good quality items can be entered into the question bank, bad items can be revised, and bad items replaced with new questions.
\end{abstract}

Keywords: distinguishing features, effectiveness of options, difficulty levels 
How to Cite: Halik, A.S., Mania, S., \& Nur, F. (2019). Analisis butir soal Ujian Akhir Sekolah (UAS) mata pelajaran matematika pada tahun ajaran 2015/2016 SMP Negeri 36 Makassar. Al-Asma: Journal of Islamic Education, 1(1), 11-17.

\section{PENDAHULUAN}

Evaluasi pendidikan adalah proses penilaian yang tidak dapat dipisahkan dari kegiatan pembelajaran untuk mengetahui hasil dari tujuan pendidikan (Tutut kurniawan, 2015). Evaluasi dilakukan untuk mengetahui sejauh mana tujuan pendidikan tercapai (Ali Hamzah, 2014). Tujuan dilakukannya evaluasi pendidikan adalah untuk mengetahui sejauh mana pengetahuan peserta didik sehingga dapat diketahui tingkat kecerdasannya. Evaluasi juga dapat membantu pihak guru dan sekolah untuk mengetahui apakah proses pembelajaran yang dilakukan berhasil dan proses pendidikan yang ada disekolah baik.

Alat yang digunakan dalam proses evaluasi dapat berupa tes maupun non tes (Purwanti, 2014). Tes adalah alat untuk mengukur hasil belajar siswa dengan memberikan seperangkat pertanyaan, pernyataan, atau serangkaian tugas yang harus dikerjakan atau dijawab oleh peserta didik (Tutut kurniawan, 2015). Tes merupakan alat ukur yang paling sering digunakan guru untuk mengukur hasil belajar siswa. Tes yang biasa digunakan guru atau sekolah untuk menguji hasil belajar siswa ada dua yaitu tes dalam bentuk soal esai dan soal pilihan ganda. Tes dalam bentuk soal esai biasanya adalah soal ulangan harian, sedangkan dalam bentuk soal pilihan ganda adalah soal ujian akhir semester atau ujian akhir sekolah.

Analisis butir soal merupakan kegiatan menganalisa soal yang dilakukan untuk mengidentifikasi soal yang baik, kurang baik atau jelek (M. Zuhdi Rachman, 2012). Analisis butir soal mencakup analisis tingkat kesukaran, daya pembeda dan efektifitas opsi. Salah satu jenis tes yang harus dianalisis adalah tes berupa soal ujian akhir sekolah yang biasanya berbentuk pilihan ganda. Soal dapat dikatakan baik apabila memenuhi kriteria tingkat kesukaran, daya pembeda, dan efektifitas opsi untuk analisis butir soal secara kuantitatif.

Tingkat kesukaran adalah peluang menjawab benar suatu soal (Aliati \& Ibrahim, 2013). Semakin banyak siswa menjawab benar suatu soal maka semakin mudah soal tersebut. Sebaliknya, semakin sedikit siswa yang menjawab benar suatu soal maka semakin sukar soal tersebut (Ali Hamzah, 2014). Soal yang baik adalah soal yang tidak terlalu sukar atau terlalu mudah. Soal yang terlalu mudah tidak merangsang siswa untuk meningkatkan usaha dalam memecahkan soal sedangkan soal yang terlalu sukar akan menyebabkan siswa putus asa karena pemecahan soal itu diluar kemampuannya kemudian tidak lagi bersemangat untuk menyelesaikannya (Suharsimi Arikunto, 2010). Menurut (Syamsuddin, 2012) soal dapat diinterpretasikan tingkat kesukarannya dengan menghitung indeks kesukaran soal menggunakan rumus:

Dimana P : Indeks kesukaran soal

$$
P=\frac{B}{J S}
$$

B : Banyak siswa yang menjawab soal dengan benar

Js : Jumlah seluruh peserta tes

Menurut (Karunia Eka Lestari \& Mokhammad Ridwan Yudhanegara, 2015) tolak ukur untuk menginterpretasikan tingkat kesukaran soal digunakan kriteria sebagai berikut; 
Tabel 1. Interpretasi Indeks Tingkat Kesukaran

\begin{tabular}{cc}
\hline $\mathbf{P}$ & Interpretasi \\
\hline $\mathrm{P}=0,00$ & Terlalu Sukar \\
$0,00<\mathrm{P} \leq 0,30$ & Sukar \\
$0,30<\mathrm{P} \leq 0,70$ & Sedang \\
$0,70<\mathrm{P}<1,00$ & Mudah \\
$\mathrm{P}=1,00$ & Terlalu Mudah \\
\hline
\end{tabular}

Daya pembeda adalah kemampuan soal dapat membedakan siswa yang berkemampuan tinggi dengan siswa yang berkemampuan rendah. Angka yang menunjukkan besarnya daya pembeda disebut indeks diskriminasi yang berkisar antara 0,00 sampai 1,00 (Syamsuddin, 2012). Indeks daya pembeda juga dapat bernilai negatif apabila kelompok siswa berkemampuan rendah lebih banyak menjawab soal dengan benar daripada kelompok siswa berkemampuan tinggi (Sitti Mania, 2012). Menurut (Syamsuddin, 2012) indeks daya pembeda dapat dihitung menggunakan rumus :

$$
D=\frac{B a}{J a}-\frac{B b}{J b}
$$

Dimana D : Indek daya beda

Ba : Banyak siswa kelompok atas yang menjawab benar

Ja : Jumlah siswa kelompok atas

$\mathrm{Bb}$ : Banyak siswa kelompok bawah yang menjawab benar

Jb : Jumlah siswa kelompok bawah

Menurut (Karunia Eka Lestari \& Mokhammad Ridwan Yudhanegara, 2015) tolak ukur untuk menginterpretasikan daya pembeda soal digunakan kriteria sebagai berikut:

Tabel 2. Interpretasi Indeks Daya Pembeda

\begin{tabular}{cc}
\hline Indeks Daya Pembeda & Interpretasi \\
\hline $0,70<\mathrm{DP} \leq 1,00$ & Sangat Baik \\
$0,40<\mathrm{DP} \leq 0,70$ & Baik \\
$0,20<\mathrm{DP} \leq 0,40$ & Cukup \\
$0,00<\mathrm{DP} \leq 0,20$ & Buruk \\
$\mathrm{DP} \leq 0,00$ & Sangat Buruk \\
\hline
\end{tabular}

Efektifitas opsi adalah cara untuk mengetahui apakah suatu opsi pada soal berfungsi. Opsi atau pengecoh yang diberikan dapat menjadi pilihan bagi siswa ketika melakukan proses penyelesaian soal. Opsi yang menjadi pengecoh pada soal adalah opsi yang dalam penyelesaian soal karena terjadi salah konsep, salah hitung, atau salah prosedur. (Ali Hamzah, 2014) Suatu pengecoh dapat dikatakan berfungsi apabila dipilih paling sedikit $5 \%$ dari peserta tes atau lebih banyak dipilih oleh kelompok siswa yang belum paham materi. (Kementerian Pendidikan Nasional, 2010).

\section{METODE PENELITIAN}

Penelitian ini merupakan penelitian yang bersifat evaluasi dengan pendekatan deskriptif kuantitatif. Artinya, penelitian dilakukan secara kuantitatif tetapi tidak untuk menolak atau menerima hipotesis melainkan untuk menjelaskan keadaan yang apa adanya 
sesuai dengan objek yang diteliti. Penelitian ini dilakukan di SMP Negeri 36 Makassar kecamatan Biringkanaya Kota Makassar. Evaluasi dalam penelitian ini dilakukan terhadap butir soal ujian akhir sekolah (UAS) mata pelajaran matematika pada tahun ajaran 2015/2016 untuk mengetahui kualitas soal dengan cara melakukan analisis butir soal secara kuantitatif. Analisis dilakukan dengan menggunakan aplikasi Anates versi 4.09. Soal dikatakan berkualitas baik apabila memenuhi kriteria penilaian butir soal yang meliputi tingkat kesukaran, daya pembeda, dan efektifitas opsi.

\section{HASIL DAN PEMBAHASAN}

\section{Deskripsi Tingkat Kesukaran}

Berikut adalah hasil analisis tingkat kesukaran soal ujian akhir sekolah mata pelajaran matematika pada tahun ajaran 2015/2016 SMP Negeri 36 Makassar dengan menggunakan aplikasi Anates versi 4.09.

Tabel 3. Distribusi Frekuensi dan Persentase Tingkat Kesukaran Soal Ujian Akhir Sekolah (UAS) Mata Pelajaran Matematika pada Tahun Ajaran 2015/2026 SMP Negeri 36 Makassar

\begin{tabular}{llcc}
\hline \multicolumn{1}{c}{ Kriteria } & \multicolumn{1}{c}{ Nomor Soal } & Jumlah & Persentase \\
\hline Sangat Mudah & $4,34$. & 2 & $5 \%$ \\
Mudah & - & 0 & $0 \%$ \\
Sedang & $1,2,3,6,8,9,11,12,13,14,17,18,19,20$, & 24 & $60 \%$ \\
Sukar & $24,25,28,29,30,31,32,36,38,39$. & & \\
Sangat Sukar & $7,10,15,16,21,22,23,26,27,35,37,40$. & 12 & $30 \%$ \\
\hline
\end{tabular}

Berdasarkan tabel 3, soal ujian akhir sekolah (UAS) mata pelajaran matematika pada tahun ajaran 2015/2016 SMP Negeri 36 Makassar termasuk soal yang kurang baik. Hal ini dikarenakan hanya $60 \%$ soal yang baik, sementara masih ada $40 \%$ soal yang tidak baik yaitu $5 \%$ sangat mudah, $30 \%$ sukar, dan $5 \%$ sangat sukar.

Kriteria kesimpulan kualitas butir soal yang baik berdasarkan tingkat kesukaran adalah soal yang tingkat kesukarannya sedang yaitu soal dengan indeks kesukaran antara $0,30-0,70$. Soal yang baik adalah soal yang tingkat kesukarannya sedang, tidak teralu mudah atau terlalu sukar. Soal yang mudah tidak merangsang siswa untuk berpikir dalam memecahkan suatu permasalahan, sedangkan soal yang terlalu sukar membuat siswa putus ada dan tidak semangat untuk menyelesaikan masalah tersebut karena di luar jangkauan siswa. Butir soal yang baik berjumlah 24 butir yaitu nomor 1, 2, 3, 6, 8, 9, 11, 12 , $13,14,17,18,19,20,24,25,28,29,30,31,32,36,38$, dan 39 . Soal yang termasuk dalam kategori baik dapat dimasukkan ke bank soal.

Kriteria kesimpulan kualitas butir soal yang cukup baik berdasarkan tingkat kesukaran adalah soal yang tingkat kesukarannya mudah atau sukar yaitu soal dengan indeks kesukaran antara 0,00 - 0,30 atau antara 0,70 - 1,00. Butir soal yang mudah berasal dari materi yang secara umum mudah dipahami siswa dan pengecoh yang kurang berfungsi. Butir soal yang sukar berasal dari materi yang tingkat kompleksitasnya tinggi dan perlu ketelitian dalam perhitungan. Butir soal yang kurang baik berjumlah 12 butir (kategori sukar) yaitu nomor 7, 10, 15, 16, 21, 22, 23, 26, 27, 35, 37, dan 40. Soal yang 
termasuk dalam kategori cukup baik dapat dimasukkan ke bank soal dengan syarat soal tersebut sudah direvisi.

Kriteria kesimpulan kualitas butir soal yang tidak baik (jelek) berdasarkan tingkat kesukaran adalah soal yang tingkat kesukarannya sangat mudah atau sangat sukar yaitu soal dengan indeks kesukaran sama dengan 0,00 atau 1,00. Soal yang sangat mudah tidak merangsang siswa untuk berpikir dalam menyelesaikan suatu permasalahan, sedangakn soal yang sangat sukar membuat siswa putus asa dan tidak memiliki semangat untuk menjawab suatu permasalahan. Soal yang sangat mudah berasal dari materi yang sangat mudah dipahami siswa dan memiliki pengecoh yang tidak berfungsi. Butir soal yang sangat sukar berasal dari materi yang sulit dipahami siswa karena memerlukan pemahaman tingkat tinggi dan memiliki pengecoh yang tidak berfungsi. Butir soal yang tidak baik (jelek) berjumlah 4 butir ( 2 butir sangat sukar dan 2 butir sangat mudah) yaitu nomor 4, 5, 33, dan 34. Soal yang termasuk dalam kategori jelek sebaiknya dibuang dan diganti dengan soal yang baru.

\section{Deskripsi Daya Pembeda}

Berikut adalah hasil analisis daya pembeda soal ujian akhir sekolah mata pelajaran matematika pada tahun ajaran 2015/2016 SMP Negeri 36 Makassar dengan menggunakan aplikasi Anates versi 4.09 .

Tabel 4. Distribusi Frekuensi dan Persentase Daya Pembeda Soal Ujian Akhir Sekolah Mata Pelajaran Matematika pada Tahun Ajaran 2015/2016 SMP Negeri 36 Makassar

\begin{tabular}{clcc}
\hline Kriteria & \multicolumn{1}{c}{ Nomor Soal } & Jumlah & Persentase \\
\hline Sangat Jelek & $7,33,40$. & 3 & $7,5 \%$ \\
Jelek & $2,5,14,17,19,22,26,27,31,32,34,36$. & 12 & $30 \%$ \\
Cukup & $1,4,8,11,16,20,21,23,24,25,29,35$, & 14 & $35 \%$ \\
Baik & $37,38$. & 11 & $27,5 \%$ \\
Sangat Baik & $3,6,9,10,12,13,15,18,28,30,39$ & 0 & $0 \%$ \\
\hline
\end{tabular}

Berdasarkan tabel 4, soal ujian akhir sekolah mata pelajaran matematika pada tahun ajaran 2015/2016 SMP Negeri 36 Makassar dengan menggunakan aplikasi Anates versi 4.09 menunjukkan bahwa dari 40 butir soal terdapat sebanyak 3 butir $(7,5 \%)$ dengan daya pembeda sangat jelek, 12 butir (30\%) dengan daya pembeda jelek, 14 butir (35\%) dengan daya pembeda cukup, dan 11 butir (27,5\%) dengan daya pembeda baik.

Kriteria kesimpulan kualitas soal yang baik berdasarkan daya pembeda adalah soal dengan daya pembeda baik atau sangat baik yaitu soal yang memiliki indeks di atas 0,70. Soal yang baik adalah soal yang dapat membedakan siswa yang menguasai materi dan siswa yang tidak menguasai materi. Butir soal yang baik berjumlah 11 butir yaitu nomor 3 , $6,9,10,12,13,15,18,28,30$, dan 39 . Soal yang termasuk dalam kategori baik dapat dimasukkan ke bank soal.

Kriteria kesimpulan kualitas soal yang cukup baik berdasarkan daya pembeda adalah soal dengan daya pembeda cukup baik. Soal yang cukup baik adalah soal yang masih dapat membedakan siswa yang menguasai materi dengan siswa yang tidak menguasai materi. Soal yang cukup baik dapat disebabkan siswa yang tidak menguasai materi secara kebetulan menebak jawaban yang benar. Butir soal yang kurang baik 
berjumlah 14 butir yaitu nomor $1,4,8,11,16,20,21,23,24,25,29,35,37$, dan 38 . Soal yang termasuk kategori cukup baik dapat dimasukkan ke bank soal dengan syarat soal tersebut sudah direvisi.

Kriteria kesimpulan kualitas soal yang tidak baik (jelek) berdasarkan daya pembeda adalah soal dengan daya pembeda jelek atau sangat jelek. Soal yang jelek adalah soal yang tidak dapat membedakan siswa yang menguasai materi dan siswa yang tidak menguasai materi. Soal yang jelek dapat disebabkan karena banyaknya siswa yang tidak menguasai materi dapat menjawab benar soal yang diberikan. Butir soal yang tidak baik (jelek) berjumlah 15 butir (12 butir kategori jelek dan 3 butir kategori sangat jelek) yaitu nomor 2, 5, 7, 14, 17, 19, 22, 26, 27, 31, 32, 33, 34, 36, dan 40. Soal yang termasuk dalam kategori jelek sebaiknya dibuang dan diganti dengan soal yang baru.

\section{Deskripsi Efektifitas Opsi}

Berikut adalah hasil analisis efektifitas opsi soal ujian akhir sekolah mata pelajaran matematika pada tahun ajaran 2015/2016 SMP Negeri 36 Makassar dengan menggunakan aplikasi Anates versi 4.09. ;

Tabel 5. Distribusi Frekuensi dan Persentase Efektifitas Opsi Soal Ujian Akhir Sekolah Mata Pelajaran Matematika pada Tahun Ajaran 2015/2016 SMP Negeri 36 Makassar

\begin{tabular}{llll}
\hline Kategori & Nomor Soal & Jumlah & Persentase \\
\hline \multirow{2}{*}{ Sangat Baik } & $3,4,5,7,8,9,10,12,13,14,15,16,17$, & \\
& $19,20,21,22,23,24,25,27,28,29,28$ & $70 \%$ \\
Baik & $32,35,37,39,40$ & & \\
Buruk & $2,6,18,26,30,31,33,34,38$ & 9 & $22,5 \%$ \\
Sangat Buruk & $1,11,36$ & 3 & $7,5 \%$ \\
\hline
\end{tabular}

Berdasarkan tabel 5, soal ujian akhir sekolah mata pelajaran matematika pada tahun ajaran 2015/2016 SMP Negeri 36 Makassar dengan menggunakan aplikasi Anates versi 4.09 menunjukkan bahwa dari 40 butir soal terdapat sebanyak 28 butir (70\%) sangat baik, 9 butir (22,5\%) baik, dan 3 butir (7,5\%) buruk.

Kriteria kesimpulan kualitas soal yang baik berdasarkan efektifitas opsi adalah soal yang dalam kategori baik atau sangat baik (maksimal ada 1 opsi yang tidak berfungsi). Apabila semua pengecoh pada suatu soal dipilih paling tidak $5 \%$ dari peserta tes atau terdapat satu pengecoh yang tidak dipilih minimal 5\% dari peserta tes, maka soal tersebut adalah soal yang baik. Butir soal yang baik berjumlah 37 butir (28 butir sangat baik dan 9 butir baik) yaitu nomor $2,3,4,5,6,7,8,9,10,12,13,14,15,16,17,18,19,20,21,22,23$, $24,25,26,27,28,29,30,31,32,33,34,35,37,38,39$, dan 40 . Soal yang termasuk dalam kategori baik dapat dimasukkan ke bank soal.

Kriteria kesimpulan kualitas soal yang cukup baik berdasarkan efektifitas opsi adalah soal yang dalam kategori buruk (terdapat 2 opsi yang tidak berfungsi). Apabila terdapat dua pengecoh yang tidak dipilih minimal 5\% dari peserta tes, maka soal tersebut adalah soal yang cukup baik. Butir soal yang cukup baik berjumlah 3 butir yaitu nomor 1 , 11, dan 36. Soal yang termasuk dalam kategori cukup baik dapat dimasukkan ke bank soal dengan syarat soal tersebut sudah direvisi. 


\section{SIMPULAN}

Berdasarkan hasil analisis butir soal terhadap soal ujian akhir sekolah mata pelajaran matematika pada tahun ajaran 2015/2016 SMP Negeri 36 Makassar yang terdiri dari tingkat kesukaran soal, daya pembeda soal, dan keefektifan opsi dapat disimpulkan bahwa tingkat kesukaran soal; 2 butir (5\%) sangat mudah, 24 butir (60\%) sedang, 12 butir (30\%) sukar, dan 2 butir (5\%) sangat sukar. Untuk daya pembeda soal, 3 butir (7,5\%) sangat jelek, 12 butir (30\%) jelek, 14 butir (35\%) cukup baik, dan 11 butir (27,5\%) baik. Untuk efektifitas opsi; 28 butir (70\%) dalam kategori sangat baik, 9 butir $(22,5 \%)$ dalam kategori baik, dan 3 butir (7,5\%) dalam kategori buruk.

\section{DAFTAR PUSTAKA}

Ali Hamzah. (2014). Evaluasi Pembelajaran Matematika (I). Jakarta: rajawali pers.

Aliati, \& Ibrahim, M. (2013). Kualitas Tes Ujian Nasional Matematika Siswa SMP Negeri Di Kabupaten Buton Utara Tahun Ajaran 2011/2012. Jurnal Pendidikan Matematikaa, 1.

Karunia Eka Lestari, \& Mokhammad Ridwan Yudhanegara. (2015). Penelitian Pendidikan Matematika (I). Bandung: PT Refika Aditama.

Kementerian Pendidikan Nasional. (2010). Panduan analisis butir soal.

M. Zuhdi Rachman. (2012). Kajian Butir Soal Ujian Sekolah Matematika SMA Negeri 1 Gongdanglegi Tahun 2012. Artikel.

Purwanti, M. (2014). Analisis Butir Soal Ujian Akhir Mata Pelajaran Akuntansi Keuangan Menggunakan Microsoft Office Excel 2010. Jurnal Pendidikan Akuntansi Indonesia. https://doi.org/10.21831/jpai.v12i2.2710.

Sitti Mania. (2012). Pengantar Evaluasi Pengajaran. Makassar: Alauddin University Press.

Suharsimi Arikunto. (2010). Dasar-dasar Evaluasi Pendidikan. Jakarta: Bumi Aksara.

Syamsuddin. (2012). Pengukuran Daya Pembeda, Taraf Kesukaran, dan Pola Jawaban Tes (Analisis Butir Soal). At-Tajdid, 1(2).

Tutut kurniawan. (2015). Analisis Butir Soal Ulangan Akhir Semester Gasal Mata Pelajaran Ips Sekolah Dasar. Journal of Elementary Education. 